\title{
Pengaruh intensitas pembelajaran ekonomi dalam keluarga, intensitas komunikasi dengan teman sebaya terhadap perilaku konsumsi mahasiswa program studi S1 pendidikan ekonomi angkatan 2018 Universitas Negeri Malang
}

\author{
Destha Rarantika Gandhi, Wahjoedi*, Sri Umi Mintarti, Yohanes Hadi Soesilo \\ Universitas Negeri Malang, Jl. Semarang No. 5 Malang, Jawa Timur, Indonesia \\ *Penulis korespondensi, Surel: wahjoedi.fe@um.ac.id
}

Paper received: 25-8-2021; revised: 8-9-2021; accepted: 15-9-2021

\begin{abstract}
The current rapid modernization must also have an influence on students' consumption. This study aims to determine the effect of the independent variable, namely the intensity of economic learning in the family and the intensity of communication with peers on the dependent variable, namely the consumption behavior of the 2018 Economics Education S1 students, State University of Malang partially and simultaneously. This research is a quantitative research with the type of explanatory research which aims to explain the influence of the independent variable on the dependent variable and to find out how much influence these variables have. Suggestions from this study are: (1) students are expected to be able to apply economic learning that has been taught in the family to realize rational consumption behavior in daily life, 2) students are expected to be in a peer environment and be able to bring good influence because they have received economic learning from his family so that he is able to consume rationally.
\end{abstract}

Keywords: family economics learning; peers; consumption behavior

\begin{abstract}
Abstrak
Pesatnya kemajuan saat ini membawa pengaruh pada konsumsi para siswa. Penelitian ini bertujuan untuk menentukan efek dari variable bebas, berupa intensitas pembelajaran ekonomi dalam keluarga dan komunikasi dengan teman sebaya, pada variable terikat, yaitu perilaku konsumsi dari mahasiswa S1 pendidikan ekonomi Universitas Negeri Malang. Penelitian ini merupakan penelitian kuantitatif tipe eksplanatori yang bertujuan untuk mengetahui besarnya pengaruh dari variable bebas pada variable terikat. Dari hasil yang didapatkan, maka: 1) para mahasiswa diharapkan mampu menggunakan pembelajaran ekonomi yang sudah di dapatkan di keluarga untuk mewujudkan perilaku konsumsi rasional dalam kehidupan sehari-hari, 2) para mahasiswa juga diharapkan untuk mempunyai lingkungan teman sebaya dan mampu memberikan pengaruh baik karena mereka telah mendapatkan pembelajaran ekonomi yang dapat menuntun mereka untuk melakukan konsumsi rasional.
\end{abstract}

Kata kunci: pendidikan ekonomi keluarga; teman sebaya; perilaku konsumsi

\section{Pendahuluan}

Pesatnya modernisasi saat ini pasti juga membawa pengaruh pada setiap perilaku individu dalam berkonsumsi, masuknya budaya barat yang sedikit-banyak berefek pada berubahnya sikap seseorang yang tadinya berperilaku produktif saat ini cenderung berperilaku konsumtif. Di Indonesia, budaya lokal mulai menguap digantikan dengan masuknya budaya barat yang dikira semakin bertambah modern. Seperti yang dijelaskan Aryudi dalam Dian (2011) beberapa negara maju juga mulai melaksanakan perluasan pasar guna memenuhi kebutuhan di masyarakat. Para produsen akan berupaya menghasilkan budaya konsumtif guna memasarkan produknya. Akhirnya budaya konsumtif akan berdampak 
di lingkungan masyarakat. Golongan masyarakat yang mempunyai tingkat serta kualitas pendidikan yang lebih tinggi akan mendapatkan peluang yang lebih besar untuk memperoleh pekerjaan, sehingga mempunyai peluang yang lebih besar pula untuk memperoleh penghasilan yang tinggi. Golongan masyarakat yang memiliki penghasilan tinggi ini akan menjadi segmen konsumen yang mempengaruhi pasar.

Mahasiswa Pendidikan Ekonomi angkatan 2018 yang berada pada fase remaja pada jarak usia antara 19-20 tahun. Pada tahun ketiga ini mereka cenderung berkumpul bersama teman kelompoknya yang memiliki minat serta kecocokan yang sama antara antara satu dengan yang lainnya, dari sinilah pengaruh perilaku konsumtif mulai muncul dan terbentuk diantara kelompok teman sebaya. Dalam kehidupan mahasiswa juga tidak bisa terlepas dari kegiatan konsumsi, sebab pada dasarnya manusia mempunyai bermacam-macam tuntutan kebutuhan guna mendukung proses kehidupan. Kegiatan konsumsi bisa memunculkan sebuah masalah apabila mereka lebih mendahulukan keinginannya dibandingkan dengan kebutuhannya. Oleh sebab itu dalam melaksanakan kegiatan ekonomi manusia wajib berfikir secara rasional, sehingga bisa memperhitungkan pengorbanan serta hasil yang akan diperolehnya. Komunikasi yang terjalin di lingkungan mahasiswa juga memberikan pengaruh yang besar, pada kondisi ini dikarenakan mereka memiliki jarak usia yang tidak terlalu jauh dengan pola pikir yang hampir sama pula, sehingga mereka akan merasa nyaman ketika mereka melakukan suatu kegiatan ekonomi. Universitas Negeri Malang merupakan universitas yang banyak dikelilingi oleh pusat perbelanjaan, kuliner, maupun tempat-tempat lainnya yang cenderung untuk membuat seseorang terus ingin melakukan kegiatan konsumsi. Contohnya ada Malang Town Square yang berada tepat di depan Universitas negeri Malang, Mall Olympic Garden yang berada di Jl. Kawi, Malang City Point yang berada di Jl. Terusan Dieng merupakan tempat yang paling dekat dengan kampus dan paling banyak diminati oleh mahasiswa untuk melakukan kegiatan dalam berkonsumsi.

Kelompok teman sebaya dijelaskan oleh Havighurst bahwa sebuah perkumpulan orang yang memiliki usia yang hampir sama yang berpikir serta bertindak secara bersama-sama (Hurlock, 1993: 264). Teman sebaya bisa membawa pengaruh yang cukup besar bagi seseorang dalam berperilaku konsumtif. Perilaku konsumtif yang terjadi di lingkungan mahasiswa ini bukan merupakan fenomena yang langka. Mereka akan cenderung untuk membeli suatu produk bukan untuk kebutuhannya melainkan untuk mengikuti trend, terpengaruh dengan teman sebaya, ataupun ingin mendapatkan sebuah pengakuan sosial di lingkungannya. Santrok (2003:26) juga menjelaskan bahwa "Kelompok konsumen pada usia remaja biasanya mudah terpengaruh dengan iklan, teman sebaya, serta cenderung boros dalam mengeluarkan uangnya serta seringkali bertindak tidak realistis". Sebagai contoh, banyaknya e-commerce yang menawarkan diskon besar-besaran menjelang Hari Raya. Make up dan Fashion (Pakaian, tas, sepatu) adalah 2 hal yang diminati oleh mahasiswa saat ini. Mereka akan lebih peka terhadap apa yang sedang viral di media sosial atau yang sedang menjadi trend dikalangannya. Demi memenuhi keinginannya mereka akan membeli barangbarang tersebut, apalagi barang yang mereka cari menawarkan diskon yang sangat besar. Kegiatan yang mereka lakukan secara berlebihan ini tentunya akan mengakibatkan pemborosan. Pada saat masa remaja pengaruh dari teman sebaya maupun sesama remaja sangat kuat, karena untuk pertama kalinya mereka akan mulai untuk menerapkan dan juga menjalankan prinsip untuk hidup bersama dan bekerja sama yang merupakan penjelasan dari Muhammad Al-Mighwar (2006:124). Selain itu juga terdapat pengaruh yang besar dari orang 
tua, kesukaan, bahkan kepribadian maupun kebiasaan anak pada usia remaja banyak dipengaruhi oleh teman serta kelompok sebayanya.

Selain teman sebaya, pembelajaran ekonomi dalam keluarga juga memiliki pengaruh terhadap pola pikir secara rasional dalam berperilaku konsumtif. Pembelajaran ekonomi disini akan memiliki suatu peranan yang sangat penting bagi anak ketika akan melakukan suatu kegiatan dalam perekonomian, salah satunya kebijaksanaan dalam berkonsumsi. Menurut alfin \& susanti (2014: 5) keluarga merupakan tempat yang mempunyai pengaruh yang besar untuk mensosialisasikan pengelolaan keuangan anak pada usia remaja atau mahasiswa karena lebih banyak menghabiskan waktu dirumah, sehingga hal ini akan mempengaruhi pendidikan anak mengenai literasi keuangannya. Pembelajaran ekonomi pada lingkungan keluarga menjadi dasar pendidikan yang sangat berguna bagi seorang anak, karena ketika anak tersebut sudah bergabung dengan kelompoknya dia bisa mengelola keuangan dengan baik dan mengerti bagaimana membelanjakan uang tersebut sesuai dengan kebutuhannya bukan semata-mata mengikuti keinginannya dan menjadikan kebiasaan tersebut menjadi gaya hidup yang berlebihan. Semakin baik keluarga memberikan pendidikan ekonomi kepada anak maka semakin baik pula logika yang akan digunakan ketika dia berkumpul dengan lingkungan teman sebayanya sebab anak tersebut sudah memiliki prinsip dan pola pikir yang dewasa dan bijaksana dalam mengelola keuangan juga membelanjakan uangnya.

Berdasarkan permasalahan diatas, maka penulis tertarik untuk meneliti perilaku konsumsi yang terjadi dikalangan mahasiswa dengan mengambil judul penelitian "Pengaruh Intensitas Pembelajaran Ekonomi Dalam Keluarga, Intensitas Komunikasi Dengan Teman Sebaya Terhadap Perilaku Konsumsi Mahasiswa Program Studi S1 Pendidikan Ekonomi Angkatan 2018 Universitas Negeri Malang"

\section{Metode}

Rancangan penelitian ini adalah rancangan penelitian kuantitatif. Jenis penelitian yang digunakan adalah penelitian eksplanasi dimana jenis penelitian eksplanasi ini bertujuan untuk mengetahui pengaruh variabel intensitas pembelajaran ekonomi dalam keluarga (X1) dan intensitas komunikasi dengan teman sebaya (X2) terhadap perilaku konsumsi (Y) mahasiswa S1 pendidikan ekonomi angkatan 2018 Universitas Negeri Malang.

Populasi dalam penelitian ini adalah mahasiswa program studi S1 Pendidikan Ekonomi angkatan 2018 Universitas Negeri Malang dengan jumlah keseluruhan sebanyak 131 mahasiswa yang terdiri dari 6 offering. Metode pengambilan sampel menggunakan teknik simple random sampling dan diperoleh sampel sebanyak 99 mahasiswa.

Pengumpulan data intensitas pembelajaran ekonomi dalam keluarga (X1), intensitas komunikasi dengan teman sebaya (X2), dan perilaku konsumtif (Y) menggunakan angket. Sedangkan teknik analisis yang digunakan adalah analisis regresi linear berganda dengan menggunakan program IBM SPSS Statistics 22. Adapun pengujian hipotesis menggunakan uji t dan uji F.

\section{Hasil dan Pembahasan}

Hasil analisis data dalam penelitian ini dapat dilihat pada tabel 1 (Hasil uji t) dan tabel 2 (Hasil uji F) berikut ini. 
Tabel 1. Hasil Uji t (Parsial)

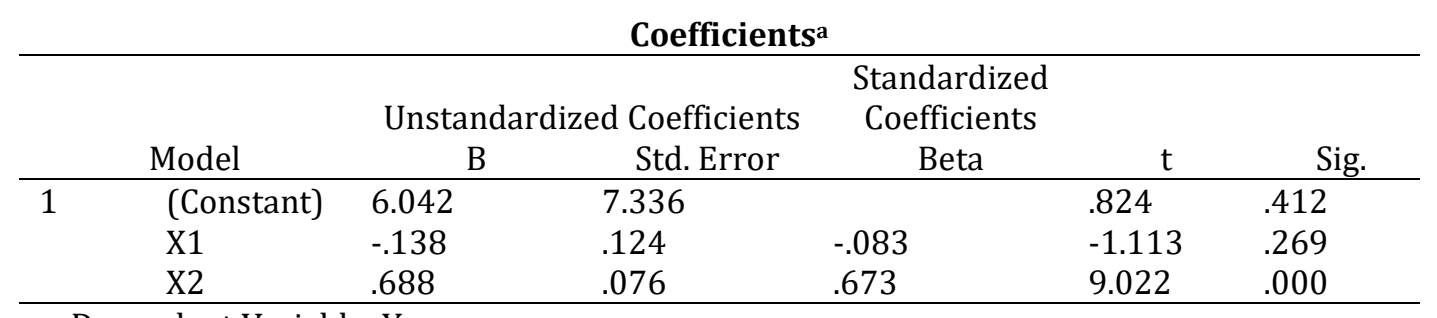

a. Dependent Variable: $Y$

Berdasarkan tabel 1 di atas, dapat dilihat bahwa nilai Sig. untuk Intensitas Pembelajaran Ekonomi dalam Keluarga $\left(\mathrm{X}_{1}\right)$ sebesar 0,269 dan besarnya $t_{\text {hitung }}$ yaitu $-1,113$ sedangkan besarnya $t_{\text {tabel }}$ yaitu 1,985 pada penelitian ini $t_{\text {hitung }}(-1,113)<t_{\text {tabel }}(1,985)$ dan Sig $(0,269)>$ 0,05, maka dapat disimpulkan bahwa $\mathrm{H}_{1}$ diterima yang artinya variabel Intensitas Pembelajaran Ekonomi dalam Keluarga $\left(\mathrm{X}_{1}\right)$ berpengaruh secara negatif terhadap Perilaku Konsumsi (Y) mahasiswa S1 Pendidikan Ekonomi angkatan 2018 Universitas Negeri Malang. Tanda (-) pada variabel $\mathrm{X}_{1}$ memiliki arti bahwa intensitas pembelajaran ekonomi berpengaruh negatif (berlawanan arah) terhadap perilaku konsumsi mahasiswa.

Dapat dilihat bahwa nilai Sig. untuk variabel Intensitas Komunikasi dengan Teman Sebaya $\left(\mathrm{X}_{2}\right)$ sebesar 0,000 dan besarnya $t_{\text {hitung }}$ yaitu 9,022 sedangkan besarnya $t_{\text {tabel }}$ yaitu 1,985 pada penelitian ini $t_{\text {hitung }}(9,022)>t_{\text {tabel }}(1,985)$ dan Sig $(0,000)<0,05$, maka dapat disimpulkan bahwa $\mathrm{H}_{1}$ diterima yang artinya variabel Intensitas Komunikasi dengan Teman Sebaya $\left(\mathrm{X}_{2}\right)$ berpengaruh secara positif terhadap variabel Perilaku Konsumsi (Y) mahasiswa S1 Pendidikan Ekonomi angkatan 2018 Universitas Negeri Malang.

Tabel 2. Hasil Uji F (Simultan)

\begin{tabular}{lllllll}
\multicolumn{8}{c}{ ANOVA $^{\mathbf{a}}$} \\
\hline & Model & Sum of Squares & $\mathrm{df}$ & Mean Square & F & Sig. \\
\hline 1 & Regression & 4850.190 & 2 & 2425.095 & 42.310 & $.000^{\mathrm{b}}$ \\
& Residual & 5502.436 & 96 & 57.317 & & \\
& Total & 10352.626 & 98 & & & \\
\hline
\end{tabular}

a. Dependent Variable: $Y$

b. Predictors: (Constant), X2, X1

Berdasarkan tabel Anova 2 di atas nilai Sig. yang diperoleh kedua variabel bebas yaitu Intensitas Pembelajaran Ekonomi dalam Keluarga, Intensitas Komunikasi dengan Teman Sebaya yaitu 0,000 pada tingkat alpha $0,05 \mathrm{~F}_{\text {hitung }}$ sebesar 42,310 sedangkan $\mathrm{F}_{\text {tabel }}$ sebesar 3,09. Pada penelitian ini $F_{\text {hitung }}(42,310)>F_{\text {tabel }}(3,09)$ dan Sig. $(0,000)<0,05$, maka dapat disimpulkan bahwa $\mathrm{H}_{\mathrm{a}}$ ditolak dan $\mathrm{H}_{1}$ diterima yang artinya bahwa Intensitas Pembelajaran Ekonomi dalam Keluarga, Intensitas Komunikasi dengan Teman Sebaya berpengaruh positif terhadap Perilaku Konsumsi (Y) mahasiswa S1 Pendidikan Ekonomi angkatan 2018 Universitas Negeri Malang. 


\subsection{Pengaruh Intensitas Pembelajaran Ekonomi Dalam Keluarga Terhadap Perilaku Konsumsi Mahasiswa Program Studi S1 Pendidikan Ekonomi Angkatan 2018 Universitas Negeri Malang}

Intensitas pembelajaran ekonomi dalam keluarga memiliki pengaruh negatif terhadap perilaku konsumsi, tanda negatif (-) pada variabel tersebut memiliki arti bahwa pembelajaran ekonomi dalam keluarga berpengaruh negatif (berlawanan arah) terhadap perilaku konsumtif mahasiswa. Hal ini berarti semakin tinggi pembelajaran ekonomi yang terjadi dalam keluarga maka tingkat konsumtif mahasiswa akan semakin menurun dan bisa dikatakan bahwa pembelajaran ekonomi dalam keluarga yang terjadi berjalan dengan semestinya. Sehingga pembelajaran ekonomi yang diberikan oleh orang tua kepada anak memberikan pengaruh kepada anak, melalui pembiasaan-pembiasaan yang sudah diberikan sedari mereka kecil juga keteladanan maupun penjelasan yang telah diberikan sehingga dapat merubah pola pikir anak ini menjadi lebih baik. Pengaruh secara langsung terhadap perilaku pembelian dalam setiap hari adalah keluarga. Maka dari itu, orang tua maupun keluarga berperan sangat penting dalam memberikan perhatian terhadap anak juga memberikan panutan mengenai gaya hidup sehingga anak akan lebih baik dalam berperilaku konsumtif.

\subsection{Pengaruh Intensitas Komunikasi Dengan Teman Sebaya Terhadap Perilaku Konsumsi Mahasiswa Program Studi S1 Pendidikan Ekonomi Angkatan 2018 Universitas Negeri Malang}

Intensitas komunikasi dengan teman sebaya memiliki pengaruh positif terhadap perilaku konsumsi mahasiswa. Hal ini didukung dengan hasil penelitian yang menghasilkan variabel intensitas komunikasi dengan teman sebaya memiliki pengaruh secara parsial terhadap perilaku konsumsi mahasiswa karena memiliki nilai signifikan kurang dari 0,05. Hasil ini menjelaskan bahwa semakin sering mahasiswa dalam berinteraksi dengan teman sebayanya maka akan semakin tinggi pula mereka dalam berperilaku konsumtif, begitupun sebaliknya semakin jarang mereka berinteraksi dengan teman sebayanya maka perilaku konsumtif mahasiswa akan menurun. Dijelaskan bahwa dalam suatu kelompok teman sebaya/remaja merupakan tempat bagi mereka untuk saling bertukar informasi dan juga menjadi perbandingan mengenai apa yang ada di luar lingkungan keluarganya. Interaksi yang tercipta ini akan menumbuhkan hobi maupun kesukaan yang sama dan juga pemikiran yang sama pula. Semakin sering interaksi komunikasi yang terjalin dalam pertemanan mereka bisa membawa dampak positif maupun dampak negatif bagi diri mereka sendiri dalam berperilaku konsumtif.

\subsection{Pengaruh Intensitas Pembelajaran Pendidikan Ekonomi dalam Keluarga, Intensitas Komunikasi dengan Teman Sebaya Terhadap Perilaku Konsumtif Mahasiswa Pendidikan Ekonomi Angkatan 2018 Universitas Negeri Malang}

Kedua variabel bebas berpengaruh secara signifikan terhadap perilaku konsumsi mahasiswa, hal ini dapat dibuktikan dengan hasil penelitian bahwa kedua variabel bebas tersebut memiliki pengaruh secara simultan terhadap perilaku konsumsi mahasiswa karena memiliki nilai signifikansi kurang dari 0,05. Dalam penelitian ini variabel intensitas komunikasi dengan teman sebaya mempunyai pengaruh yang paling besar, hal ini dikarenakan dalam kelompok teman sebaya terdapat minat maupun kesukaan yang sama. Pertemanan mereka akan semakin intens karena adanya konformitas dari lingkungan teman sebaya itu 
sendiri, dimana seseorang akan cenderung untuk terlihat sama atau lebih dari teman sebayanya, contohnya dalam hal penampilan. Hal ini menyebabkan para mahasiswa cenderung mengeluarkan uangnya untuk memenuhi keinginannya dan juga supaya mereka bisa diterima di lingkungan teman sebayanya. Lingkungan teman sebaya yang memiliki tingkat konsumtif yang tinggi juga akan mempengaruhi mahasiswa tersebut untuk berperilaku konsumtif. Akan tetapi dengan didapatkannya pembelajaran ekonomi dalam keluarga bagi masing-masing mahasiswa dari keluarganya dapat mengurangi konsumsi mereka secara berlebihan. Sehingga, ketika mereka berkumpul dengan kelompok teman sebayanya mereka masih bisa berkonsumsi secara rasional karena telah memperoleh pembelajaran ekonomi secara sederhana dan sudah diterapkan dalam kehidupan sehari-hari baik di lingkungan keluarga maupun di lingkungan kampus mereka. Mahasiswa yang akan melakukan konsumsi akan lebih terkendali, selektif, dan rasional dalam berkonsumsi, mereka akan berkonsumsi sesuai dengan budget yang sudah mereka tetapkan dan juga kebiasaan dan keteladanan yang sudah mereka dapatkan dari pembelajaran ekonomi yang didapatkan dari keluarganya. Sehingga dapat disimpulkan bahwa pembelajaran ekonomi dalam keluarga dan komunikasi dengan teman sebaya berpengaruh secara simultan terhadap perilaku konsumtif mahasiswa.

\section{Simpulan}

Berdasarkan hasil penelitian dan pembahasan yang telah dijelaskan pada bab sebelumnya, maka kesimpulan yang dapat ditarik dari penelitian ini adalah sebagai berikut: intensitas pembelajaran ekonomi dalam keluarga secara parsial berpengaruh negatif terhadap perilaku konsumsi mahasiswa S1 Pendidikan ekonomi angkatan 2018 Universitas Negeri Malang. Hal ini berarti semakin tinggi pembelajaran ekonomi yang terjadi dalam keluarga maka akan menurunkan perilaku konsumtif mahasiswa, sehingga mahasiswa mampu berkonsumsi secara rasional.

Intensitas komunikasi dengan teman sebaya secara parsial berpengaruh positif dan signifikan terhadap perilaku konsumsi mahasiswa S1 Pendidikan ekonomi angkatan 2018 Universitas Negeri Malang. Hal tersebut disebabkan karena mahasiswa sering berinteraksi dengan lingkungan teman sebayanya. Interaksi yang tercipta ini akan menumbuhkan kesukaan maupun hobi yang sama dan juga pemikiran yang sama pula, sehingga semakin sering komunikasi yang terjalin maka bisa mengakibatkan perilaku konsumsi yang berlebihan.

Intensitas pembelajaran ekonomi dalam keluarga, intensitas komunikasi dengan teman secara simultan berpengaruh positif dan signifikan terhadap perilaku konsumsi mahasiswa program studi S1 pendidikan ekonomi angkatan 2018 Universitas Negeri Malang. Dalam penelitian ini intensitas pembelajaran ekonomi dalam keluarga dan intensitas komunikasi dengan teman sebaya bersama-sama menjadi faktor yang mempengaruhi perilaku konsumsi mahasiswa.

\section{Daftar Rujukan}

Abdullah, Imron. (2003). Pendidikan Keluarga bagi Anak. 2003. Cirebon: Lektur.

Agustina, N. (2018). Perkembangan Peserta Didik. Yogyakarta: Deepublish.

Anshori, M., \& Iswati, S. (2017). Metodologi Penelitian Kuantitatif. Surabaya : Airlangga University Press.

Arin Mafaza, Suci. (2015). Pengaruh Pendidikan Ekonomi Dalam Keluarga, Kelompok Teman Sebaya, Dan Iklan Terhadap Perilaku Konsumtif Siswa Kelas XI SMA Brawijaya Smart School Malang. Universitas Brawijaya Malang. 
Chrisnawati, D., \& Sri, M. A. (2011). Faktor-Faktor Yang Mempengaruhi Perilaku Konsumtif Remaja Terhadap Pakaian. Jurnal Spirits, 2(1).

Dewi, N., \& Rusdarti, R. (2017). Pengaruh Lingkungan Keluarga, Teman Sebaya, Pengendalian Diri dan Literasi Keuangan Terhadap Perilaku Konsumtif Mahasiswa. Journal of Economic Education, 6(1), 29-35.

Drifanda, V., \& Ragaan, K. (2018). Pengaruh Literasi Ekonomi dan Teman Sebaya Terhadap Perilaku Konsumsi Mahasiswa Pendidikan Ekonomi Universitas PGRI Semarang. Jurnal Ilmiah Pendidikan Ekonomi, 3(1), 36-41.

Dwi Anisaputri, Belyra. (2015). Pengaruh Pendidikan Ekonomi Keluarga, Kontrol Diri, Dan Teman Sebaya Terhadap Perilaku Konsumtif Mahasiswa Program Studi S1 Pendidikan Ekonomi Angkatan Tahun 2017 Universitas Negeri Malang.

Engel, JF., Blackwell, Roger D., Miniard, Paul W. (1994). Perilaku Konsumen (jilid 1). Jakarta: Binarupa Aksara

Firdiansyah, Y. (2016). Peranan Pendidikan Ekonomi Keluarga dalam Membentuk Perilaku Ekonomi Siswa. National Conference on Economic Education 2016.

Gunarsa, S. D. (2004). Psikologi Perkembangan Anak dan Remaja. Jakarta : Gunung Mulia.

Hanifah, N. (2016). Sosiologi Pendidikan. Sumedang: UPI Sumedang Press.

Hidayatun, U. (2015). Pengaruh Intensitas Penggunaan Media Sosial dan Dukungan dengan Teman Sebaya Terhadap Perilaku Konsumtif Pada Siswa Kelas XI SMA Muhammadiyah 3 Yogyakarta Tahun Pelajaran $2014 / 2015$.

Hurlock, E., B. (2004). Psikologi Perkembangan: Suatu Pendekatan Sepanjang Rentang Kehidupan. Jakarta : Erlangga

Inanna, I. (2018). Peran Pendidikan Dalam Membangun Karakter Bangsa Yang Bermoral. JEKPEND" Jurnal Ekonomi dan Pendidikan", 1(1), 27-33.

Inanna, I. (2020). Pentingnya Pendidikan Ekonomi Informal Dalam Mewujudkan Perilaku Ekonomi Mahasiswa Yang Rasional. JEKPEND: Jurnal Ekonomi dan Pendidikan, 3(1), 64-67.

Kanserina, D., Haris, I. A., \& Nuridja, I. M. (2015). pengaruh literasi ekonomi dan gaya hidup terhadap perilaku konsumtif mahasiswa jurusan pendidikan ekonomi universitas pendidikan ganesha tahun 2015. Jurnal Pendidikan Ekonomi Undiksha, 5(1).

Lermitte, P W \& Jennifer, M. (2004). Agar Anak Pandai Mengelola Uang Making Allowances. Jakarta : Gramedia

M. Al-Mighwar, (2006). Psikologi Remaja Petunjuk Bagi Guru dan Orang Tua. Bandung : Pustaka Setia

Fitria, E. M. (2015). Dampak online shop di instagram dalam perubahan gaya hidup konsumtif perempuan shopaholic di Samarinda. Jurnal Ilmu Komunikasi, 1(3), 117-128.

Narmaditya, B. S. (2013). Pengaruh pendidikan ekonomi keluarga terhadap perilaku konsumsi dimediasi literasi ekonomi dan gaya hidup pada mahasiswa fakultas ekonomi Universitas negeri malang angkatan 2011. Ekuitas: Jurnal Pendidikan Ekonomi, 1(1).

No, U. U. (20). Tahun 2003 tentang sistem pendidikan nasional.

Nuryanti, Lusi. (2008). Psikologi Anak. Jakarta: Indeks.

Risnawati, R., \& Wardoyo, C. (2018). Pengaruh pendidikan ekonomi keluarga, gaya hidup, modernitas individu, dan literasi ekonomi terhadap perilaku konsumtif siswa. Jurnal Pendidikan: Teori, Penelitian, Dan Pengembangan, 3(4), 430-436.

Santosa, S. (2004). Dinamika Kelompok. Jakarta : Bumi Aksara.

Santrock, J. W. (2003) Adolescene: Perkembangan Remaja, Edisi 6. Jakarta : Penerbit Erlangga.

Santrock, J. W. (2007). Perkembangan Anak, Edisi 7. Jakarta : Penerbit Erlangga.

Shalahuddinta, A. (2014). Pengaruh pendidikan keuangan di keluarga, pengalaman bekerja dan pembelajaran di perguruan tinggi terhadap literasi keuangan. Jurnal Pendidikan Akuntansi (JPAK), 2(2).

Sudaryono. (2016). Metode Penelitian Pendidikan. Jakarta : Kencana.

Sumartono. (2002). Terperangkap dalam iklan. Bandung: Alfabeta.

Suryani, I. (2017). Pentingnya Pendidikan Informal Tentang Ekonomi Pada Keluarga Transmigran. DOI: 10.17977/um022v2i22017p089. Hhtp. journal2. im. ac. id/index. php/jtppips/https://www. 
Jurnal Ekonomi, Bisnis dan Pendidikan, 1(9), 2021, 836-843

researchgate.

net/publication/322576018_Pentingnya_Pendidikan_I nformal_Tentang_Ekonomi_Pada_Keluarga_Transmigran. Diakses, 2.

Supranto, J. (2000). Statistik: Teori dan Aplikasi Edisi Keenam. Jakarta : Penerbit Erlangga.

Tambunan. (2001). Remaja dan Perilaku Konsumtif. Jakarta: Erlangga.

Tarjo. (2019). Metode Penelitian. Yogyakarta : Deepublish.

Wijayanti, A. K. (2016). Hubungan Interaksi Teman Sebaya dengan Perilaku Konsumtif Pada Siswa Kelas XI di SMA N 6 Yogyakarta. Jurnal Riset Mahasiswa Bimbingan Dan Konseling, 5(2). 